DOI

\title{
ОСОБЛИВОСТІ ЗМІН ПРОЦЕСІВ ПЕРЕКИСНОГО ОКИСНЕННЯ ЛІПІДІВ ТА АНТИОКСИДАНТНОЇ СИСТЕМИ В ЛЕГЕНЯХ У РАННІЙ ПЕРІОД ФОРМУВАННЯ ЕКСПЕРИМЕНТАЛЬНОÏ ПНЕВМОНІї
}

\author{
○М. С. Регеда, Л. О. Фурдичко, М. М. Регеда-Фурдичко, С. М. Регеда \\ Львівський національний медичний університет імені Данила Галицького
}

РЕЗЮМЕ. У роботі показано, що експериментальна пневмонія супроводжується підвищенням показників прооксидантної (дієнових кон'югатів і малонового діальдегіду) та антиоксидантної систем (супероксиддисмутази, каталази, глутатіонпероксидази, глутатіонредуктази) в легенях на 4 і 8 доби цієї експериментальної моделі хвороби.

КЛЮчОВІ СлОВА: експериментальна пневмонія, антиоксидантна система, пероксидне окислення ліпідів.

Вступ. У сучасній пульмонології найактуальнішим і досі недостатньо вивченим аспектом інфекційної патології $\epsilon$ пневмонія. Власне ця патологія займає 10 \% від усіх захворювань легень і $\epsilon$ досить поширеною. Згідно з статистичними даними, в Україні щороку на пневмонію хворіє близько 180-230 тис. осіб. У країнах Європи частота захворювання складає до 11 випадків на 1000 тис. населення, а у США протягом року виявляють до 1 млн випадків захворювання на пневмонію. Середня тривалість тимчасової непрацездатності складає 26 днів. За останні роки летальність від пневмонії зросла до $10 \%$, а за умов її тяжких ускладнень у реанімаційних відділеннях і до 50 \%. Досить актуальним $є$ питання вивчення пневмоній у дітей раннього віку, адже вона дуже часто спостерігається у дітей першого року життя. Висока її летальність у цей період доводить, що пневмонія $\epsilon$ основною 3 причин дитячої смертності. Відомо, що у дорослому віці це захворювання у чоловіків зустрічається у 1,5 раза частіше, ніж у жінок. Отже, пневмонія $\epsilon$ важливою медико-соціальною проблемою, яка характеризується високими показниками захворюваності та смертності, а також значними економічними витратами на лікування $[1,2]$.

На сьогодні уже відомі причини розвитку пневмонії, проте до кінця не вивчені її механізми.

Особливу увагу як експериментатори так і клініцисти приділяють питанням щодо змін процесів перекисного окиснення ліпідів (ПОЛ) за умов розвитку формування запалення легень [3, 4], оскільки відомо, що надмірне утворення продуктів ліпопероксидації чинить пошкоджувальний вплив на легені і зумовлює розвиток пневмонії. Не дивлячись на багаточисленність наукових робіт, які присвячені вивченню процесів ПОЛ при запаленні легень, у доступній нам літературі не висвітлено, як змінюються показники прооксидантної і антиоксидантної систем у легенях в ранній період (4 і 8 доби) розвитку експериментальної пневмонії (ЕП). Разом з тим ми будемо в майбут- ньому вивчати особливості змін показників ПОЛ і АОС в легенях не лише в ранній, але й у пізній період розвитку ЕП окремо та за умов формування іншої супутньої патології, зокрема пародонтиту, та вплив на них препарату тіотриазоліну.

Метою нашого дослідження було з'ясувати роль і значення процесів ліпопероксидації та антиоксидантного захисту (АОЗ) у патогенезі розвитку раннього періоду експериментальної пневмонії (ЕП).

Матеріал і методи дослідження. Експериментальні дослідження проводили на 39 морських свинках - самцях масою 0,18-0,21 кг. Морські свинки були поділені на три групи:

- перша група - інтактні тварини (контроль) (15 тварин);

- друга група - морські свинки з експериментальною пневмонією на 4 добу (12 тварин);

- третя група - морські свинки з експериментальною пневмонією (ЕП) на 8 добу (12 тварин).

3 літератури відомо, що будь-який запальний процес перебігає у вигляді наступних стадій: інкубаційний період, продром і розпал хвороби (розвиток, розгорнута картина, криза і завершення клінічних проявів) [1, 2]. Отже ранній період у нашій роботі відповідає розвитку та кризі ЕП.

Для інтерпретації одержаних даних та їх подання умовно виділяли два періоди: ранній морські свинки на 4 і 8 доби розвитку ЕП, пізній період - тварини з ЕП після 10 діб.

Експериментальну пневмонію відтворювали за методом В. Н. Шляпникова, Т. Л. Солодової, А. С. Степанової [5].

Згодом морських свинок декапітували під ефірним наркозом на 4 та 8 доби формування запального процесу в легенях і інтактних тварин та забирали легені для біохімічних досліджень.

Визначали вміст дієнових кон'югатів (ДК) в легенях за методом В. Г. Гаврилова, В.І.Мішкорудної [6], малонового діальдегіду (МДА) - за методом Е. Н. Коробейнікова [7], активність глутатіонпер- 
Огляди літератури, оригінальні дослідження, погляд на проблему

оксидази (ГПО) - за методом О. Г. Архиповой [8], а активність глутатіонредуктази (ГР) - за методом В. М. Моїна [9], активність супероксиддисмутази (СОД) - за методом R. Fried [10], активність каталази (KT) за методом R. Holmes, C. Masters [11].

Отримані цифрові результати досліджень опрацьовували статистично за методом Стьюдента.

Результати й обговорення. У експериментальних дослідженнях було встановлено, що запальний процес у легенях супроводжувався змінами показників прооксидантної системи в динаміці формування раннього періоду ЕП.

Зокрема вміст дієнових кон'югатів (ДК) в легенях на 4 добу цієї експериментальної моделі хвороби зростав на $16,8 \%(P<0,05)$, а пізніше, на 8 добу експерименту, відбувалося подальше підвищення рівня цього показника на $33,4 \%(P<0,05)$, порівняно з інтактною групою морських свинок, що вказує на посилення процесів перекисного окиснення ліпідів за умов формування ЕП (рис. 1).

Вивчення іншого маркера ліпопероксидації малонового діальдегіду (МДА) дало нам змогу визначити його зміни. На початку формування ЕП (4 доба) спостерігалося збільшення рівня МДА на
15,9 \% $(P<0,05)$ відносно 1 групи тварин. Далі, на 8 добу запального процесу у легенях, відбувалося зростання концентрації МДА на $31,7 \%(P<0,05)$ проти контролю, що свідчить про активацію вільнорадикального окиснення (рис. 1).

Дослідження ДК та МДА у легенях дозволило виявити зрушення показників ліпопероксидації, які поступово зростали залежно від тривалості запального процесу у легенях і досягли найвищих величин на 8 добу експерименту. Одержані результати досліджень дають підставу стверджувати про стимуляцію процесів ПОЛ та наявність механізмів пошкодження при ЕП.

Порушення показників вільнорадикального окиснення викликало зміни маркерів антиоксидантного захисту за умов формування ЕП.

Так, активність супероксиддисмутази (СОД) у легенях зростала на $16,9 \%(P<0,05)$ на 4 добу експериментальної пневмонії, порівняно з інтактною групою тварин (рис. 2).

Згодом нами встановлено, що на 8 добу ЕП спостерігалося ще більше підвищення активності СОД у легенях, на 34,8 \% $(P<0,05)$ відносно контролю (рис. 2).

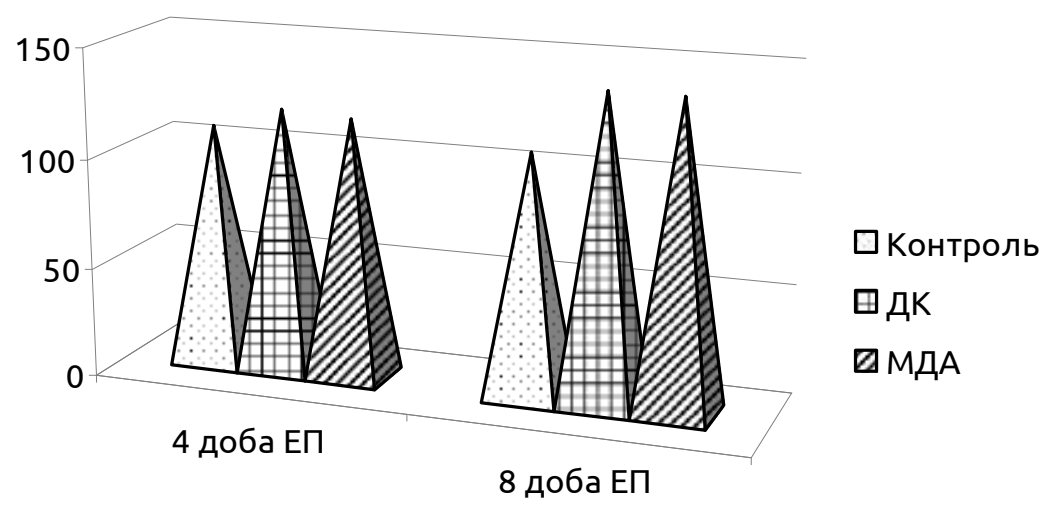

Рис. 1. Вміст продуктів ліпопероксидації у легенях при експериментальній пневмонії (\% від контролю).

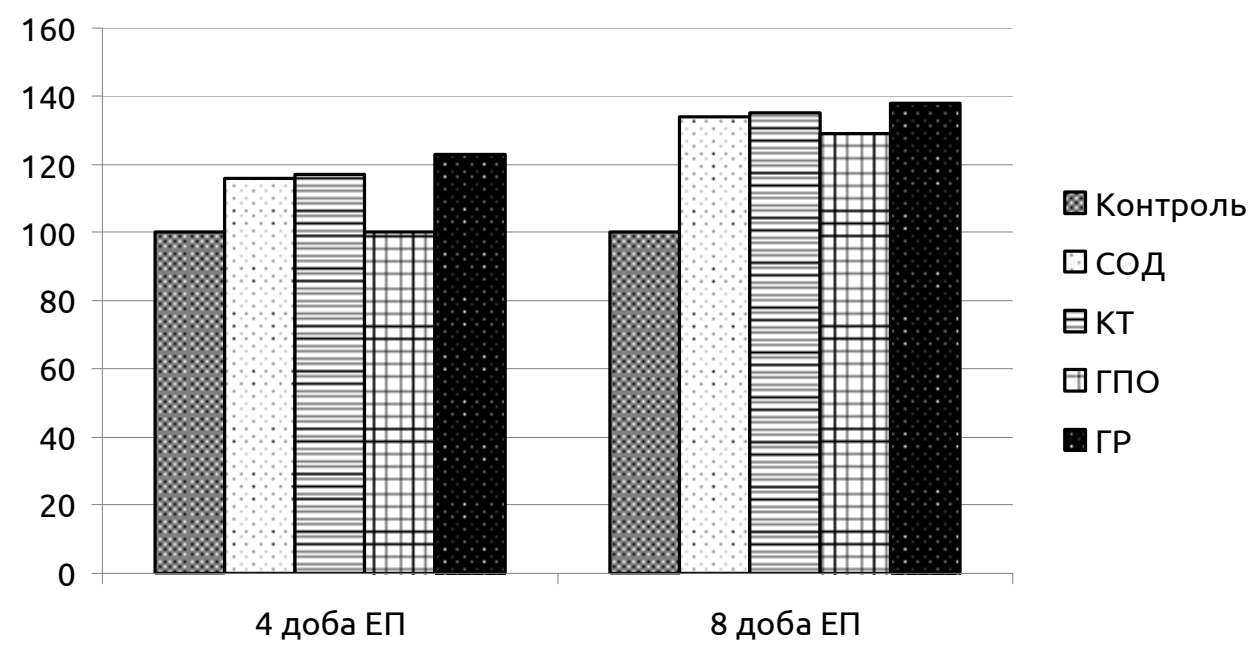

Рис. 2. Активність ферментів антиоксидантної системи у легенях при ЕП (\% від контролю). 
Огляди літератури, оригінальні дослідження, погляд на проблему

Проаналізувавши отримані результати щодо активності СОД при ЕП можна стверджувати про компенсаторну здатність цього ферменту нейтралізувати надмірно утворені продукти ПОЛ при ЕП.

Для більш повноцінної характеристики АОС проводили дослідження активності КТ. Нами показано, що на 4 добу ЕП спостерігалося зростання активності КТ на 17,3 \% $(\mathrm{P}<0,05)$ відносно контролю. Пізніше, провівши експеримент на 8 добу, ми з'ясували, що активність досліджуваного ферменту зростала на 35,4\% (P<0,05).

Наступним показником, який ми визначали у легенях при ЕП, була глутатіонпероксидаза (ГПО). Ми встановили, що на 4 добу ЕП активність ГПО не зазнавала достовірних змін і знаходилась на рівні показників групи інтактних тварин. Зате пізніше, на 8 добу, відбувалося ії помірне зростання на $29,3 \%(P<0,05)$ відносно контролю (рис. 2).

Важливе значення для оцінки стану АOC крім зазначених вище ферментів має дослідження глутатіонредуктази (ГР). На початку запального процесу у легенях (4 доба) виявлено підвищення активності ГР на 23,7 \% (P<0,05) проти першої групи тварин. Пізніше, на 8 добу експериментальної пневмонії, відбулося подальше зростання цього ензиму на 38,5 \% (P<0,05) відносно першої групи морських

\section{ЛІТЕРАТУРА}

1. Регеда М. С. Пневмонія : монографія / М. С. Регеда, М. М. Регеда, Л. О. Фурдичко. - вид. 6-те, доп. та переро6. - Львів, 2012. - 162 с.

2. Запалення типовий патологічний процес / М. С. Регеда, Т. М. Бойчук, Ю. І. Бондаренко, М. М. Регеда. - вид. 2-ге, доп. та переро6. - Львів, 2013. - 149 с.

3. Демкович А. Є. Активні форми кисню в механізмах розвитку і перебігу запальних процесів одонтогенного походження / А. Є. Демкович // Здобутки клінічної і експериментальної медицини. - 2012. - № 1 (16). - С. 51-55.

4. Гудима А. А. Дослідження процесів вільнорадикального окиснення при гострому ураженні легень / А. А. Гудима // Бюлетень Х читань ім. В. В. Підвисоцького. - Одеса, 2011. - С. 42-43.

5. Экспериментальные модели острых пневмоний, вызванных условно-патологическими бактериями и их ассоциацией : метод. указания / сост. В. Н. Шляпников, Т. Л. Солодова [и др.]. - Саратов, 1998. - 30 с.

6. Гаврилов В. Б. Спектрофотометрическое определение содержания гидроперекисей липидов в плаз- свинок, що дає підставу стверджувати про компенсаторну функцію ГР нейтралізувати надмірне утворення продуктів ліпопероксидації (рис. 2).

Підсумовуючи одержані результати наших досліджень можна констатувати, що при ЕП відбувалося поетапне надмірне утворення метаболітів вільнорадикального окиснення ліпідів та компенсаторне зростання активності ферментів АОС, яке було спрямоване на їх утилізацію з організму.

Отримані нами дані дають підстави стверджувати про врівноваження процесів ПОЛ і АОС та їх важливе значення для патогенезу пневмонії. Вивчення ПОЛ і АОС у пізньому періоді розвитку (10 і 18 доби) запального процесу в легенях і за наявності виявлення оксидантного стресу може служити основою для розробки патогенетичної терапії.

Висновки. Одержані результати досліджень дають підстави зробити висновок про те, що ЕП характеризується надмірним утворенням метаболітів ліпопероксидації на тлі компенсаторного зростання ферментативної ланки антиоксидантної системи, особливо на 8 добу експерименту, що вказує на наявність механізмів пошкодження та захисту у ранній період формування цієї експериментальної моделі хвороби.

ме крови / В. Б. Гаврилов, М. И. Мишкорудная // Лабораторная диагностика ишемической болезни сердца. К. : Здоровье, 1989. - С. 170-171.

7. Коробейникова Э. Н. Модификация определения продуктов ПОЛ в реакции с тиобарбитуровой кислотой / Э. Н. Коробейникова // Лабораторное дело. 1989. - № 7. - С. 8-10.

8. Определение активности пероксидазы в крови : методы исследования в профпатологии / под ред. О. Г. Архиповой. - М. : Медицина, 1988. - С. 153.

9. Моин В. М. Простой и специфический метод определения активности глутатионпероксидазы В эритроцитах / В. М. Моин // Лабораторное дело. 1986. - № 12. - С. 724-727.

10. Fried R. Enzymatic and non-enzymatic assay of superoxide ifilli / R. Fried // Biochemie. - 1975. - Vol. 57, № 5. - P. 657-660.

11. Holmes R. Epigenetic interconversions of the multiple forms of mouse liver catalase / R. Holmes, C. Masters // FEBS Lett. - 1970. - Vol. 11, № 1. - P. 45-48.

\title{
FEATURES OF CHANGES OF PROCESSES OF LIPID PEROXIDATION THE ANTIOXIDANT SYSTEM IN THE LUNGS IN THE EARLY PERIOD OF THE FORMATION OF EXPERIMENTAL PNEUMONIA
}

\author{
@M. S. Regeda, L. A. Furdychko, M. M. Regeda-Furdychko, S. M. Regeda \\ Danylo Galitsky Lviv National Medical University
}

SUMMARY. In the present work it is shown that the experimental pnemoniya suprovozhlaetsya povisheniem indicators prooxidation (diene conjugates and malonic deldegida) and antioxidant (superoxide dismutase, catalase, glutathione peroxidase, glutationpreduktazy) in the lungs at the 1st and the 8th day of the experimental model of the disease.

KEY WORDS: experimental pneumonia, antioxidant system, lipid peroxidation. 